\title{
Analysis of English Language Test Tasks for Seventh- and Eighth-Graders in Serbia According to Bloom's Taxonomy
}

\author{
Tatjana Glušac ${ }^{1}$ \\ Faculty of Law and Business Studies Dr Lazar Vrkatić, \\ Novi Sad, Serbia \\ Vesna Pilipović \\ Faculty of Law and Business Studies Dr Lazar Vrkatić, \\ Novi Sad, Serbia \\ Nataša Marčićev \\ Secondary School, Novi Bečej, Serbia
}

\begin{abstract}
Cognitive processes are the foundation of the cognitive domain of critical thinking. Even though developing these processes is an educational priority in many countries, including Serbia, the concept itself and the ways in which these cognitive actions can be assessed are left to teachers to discover. The aim of this paper is to investigate what cognitive processes are required of seventh-and eighth-graders in Serbia in order to complete the tasks included in English language tests. The authors collected 14 tests, designed by 14 English language teachers, for each grade. The authors analyzed the tasks and determined the levels of cognitive complexity required for completing them according to Bloom's Taxonomy for the cognitive domain while relying on the descriptions of these levels and the instructions for task classification. Generally speaking, very few tasks target higher-order thinking levels. Moreover, the teachers seem to include more cognitively demanding tasks in tests for seventh-graders. The findings raise several questions that would be worth considering in the immediate future: To what degree are English language teachers acquainted with cognitive processes and their implementation in teaching practice? Do they possess the requisite knowledge and skills for constructing tests that would successfully assess the students' ability to perform at different levels of cognitive complexity in the foreign language?
\end{abstract}

Keywords: teaching English as a foreign language, cognitive processes, critical thinking, tests, Bloom's Taxonomy.

1 tatjana.glusac@gmail.com 


\section{Introduction}

As is the case in many other countries, critical thinking is one of the educational priorities in Serbia as well. However, the meaning of the concept and the ways in which it can be taught and promoted are left to teachers to discover. During their formal education, English language teachers generally receive no, or only very little, information regarding the concept of critical thinking and its constitutive elements. Moreover, the opportunities to learn about them in professional development activities are rather scarce; hence, it is entirely up to teachers to reach a full understanding of the concept and find appropriate ways to instill the associated skills in their students. In order for teachers to discover whether their students have acquired those skills and whether any improvement is still needed, they would need to conduct assessments that would require their students to display abilities to perform tasks at different levels of cognitive capacity.

This paper aims to explore what cognitive processes, as parts of the cognitive domain of critical thinking, are required of seventh- and eighth-graders in Serbia for completing tasks in English language tests. More precisely, the aim is to determine whether teacher-made tests assessing students' knowledge of English as a foreign language contain tasks at the higher-order thinking level, which would imply students' ability to use the language independently and for communication purposes, which is the ultimate goal of foreign language teaching/learning. It needs to be stated very clearly that it is not the authors' intention to criticize the participant teachers' test-designing skills, but to shed light on the difficulty they are facing - a situation in which they are required to promote and thus monitor the development of their students' cognitive processing, yet are given no resources, tools, or guidance for how to do so.

\section{Critical thinking and English language teaching and assessment}

It is exceptionally hard to give a comprehensive and precise definition of critical thinking since it is composed of many skills and sub-skills, comprises different levels of complexity, and involves numerous personal traits. Critical thinking comprises the cognitive and the non-cognitive domain. The former is commonly defined by the evaluation of various intellectual products (ideas, beliefs, etc.) in order to determine their qualities, such as relevance, validity, groundness on evidence, etc. (Pešić, 2011, p. 7). Authors such as Cohen, Salas and Riedel (2002) and Halpern (2003) add to this the metacognitive aspect of the cognitive domain, claiming it is equally important for an individual to evaluate the product as it is to evaluate the very process of thinking. More precisely, a person needs to be capable of monitoring his/her own thinking process in order to correct misconceptions, notice sources of potential conceptual mistakes, etc. These cognitive actions presuppose a number of cognitive processes, such as analysis, interpretation, drawing conclusions, and the like. Besides evaluation and metacognition as forms of critical thinking cognitive capacities, critical thinking encompasses a number of non-cognitive qualities. These include dispositions or habits of mind (Facione, 1990), such as open- and fair-mindedness, inquisitiveness, flexibility, a desire to be well-informed, and the like (Lai, 2011). Additionally, it is paramount for a critical thinker to possess 
a number of personal traits such as systematicity, perseverance, tolerance, activism, social responsibility, etc. (Mirkov \& Stokanić, 2015, p. 26). This paper deals only with the cognitive domain of critical thinking. More precisely, it examines various levels of complexity of cognitive processes required for completing the tasks included in English language tests.

Bloom and his associates (Bloom, Englehart, Furst, Hill, \& Krathwohl, 1956) proposed a taxonomy of educational objectives related to cognitive, affective and psychomotor domains of development, specifying how students would be expected to be changed by the educative process (Bloom et al., 1956, p. 26). By doing so, they attempted to facilitate communication and understanding of the outcomes among different individuals and institutions responsible for designing or achieving them. Speaking of the cognitive domain, Bloom et al. (1956) asserted that educational objectives and respective cognitive processes could be arranged into six hierarchically organized levels: (1) knowledge, (2) understanding, (3) application, (4) analysis, (5) synthesis, and (6) evaluation. The first level presupposes storing information and one's ability to retrieve it and serves as a basis for all other ends or purposes of education (Bloom et al., 1956, p. 33). The subsequent levels are, thus, cumulative in that "the objectives in one class are likely to make use of and be built on the behaviors found in the preceding classes" (Bloom et al., 1956, p. 18). Hence, the taxonomy explains the progression from simple to complex behaviors, from the concrete or tangible to the abstract or intangible (Bloom et al., 1956, p. 30), from lower-order cognitive processes (knowledge, understanding, analysis) to higher-order cognitive processes (application, synthesis, evaluation). The former group does not presuppose complex mental processing, while the latter is considered to form one's capacity to think critically (Kennedy et al., 1991, as cited in Lai, 2011, p. 8) since students must perform several cognitive processes of different complexity to deal with a novel situation. The aim of our paper is to discover what cognitive processes are required from the seventh- and eighth-graders in our sample in order to complete the tasks in their English language tests, with an emphasis on higher-order processes, as they presuppose independent and creative language use, which is the overarching aim of foreign language learning.

Though there are certain discrepancies in their definitions of critical thinking, owing to its rather complex nature and contrasting approaches to it (e.g., philosophical, cognitivist), different authors agree that critical thinking yields benefits beyond academic success. It represents an exceptionally important life skill without which it is impossible to thrive in today's world. In that regard, critical thinking may be referred to as a global skill, but its application presupposes a thorough understanding of the domain in which it is to be applied (Cohen et al., 2002; Halpern, 2003). In addition, this skill can be viewed within the confines of the classroom - as a content-dependent skill, which is dependent upon the type of reasoning typical of a specific discipline (Glaser, 1984; McPeck, 1981; Paul \& Elder, 2008). Cognitive processes do not evolve completely naturally, nor are they gained simply as one grows up; rather, they need to be taught carefully and practiced continually from an early age. In the school context, it is necessary for any subject teacher to foster development of cognitive processes (Paul \& Elder, 2008, p. 88) and use various teaching and assessment techniques that stimulate them. If this approach is adopted, knowledge ceases to be memorized and ready only for regurgitation; its acquisition is gradual, as the student 
is engaged in a number of cognitive activities that help him/her first subsume the new material within the already existing knowledge base and finally use it in novel situations (Anderson et al., 2001). Contemporary foreign language teaching is by nature dependent upon employing different cognitive processes. Namely, first one needs to remember different grammar rules, paradigms, and vocabulary items (level of knowledge) to be able to use them in very controlled situations (level of application) or to understand them when one hears them (level of understanding), before eventually progressing to finding the most adequate way of expressing oneself while choosing among different options (level of analysis), to finally using language in novel situations, which requires the synthesis of different types of linguistic knowledge and skills. The ultimate goal of foreign language learning is communication, i.e., independent, creative use of the language, corresponding to higher-order cognitive processes (e.g., levels of synthesis and/or evaluation). Beyond this, the foreign language classroom is a suitable context for the promotion of overall critical thinking capacity, as students learn the cultural norms of the people whose language they are studying and are thus taught to be tolerant, open-minded, culture-sensitive, etc., all of which are important non-cognitive qualities of critical thinking. In our paper, cognitive processes are explored as content-dependent since we are investigating their presence and use in learning English as a foreign language.

In Serbia, the planned outcomes of foreign language education both for the seventh and the eighth grade (Rulebook on the Curriculum for the Seventh Grade of Elementary School, 2018; Rulebook on the Curriculum for the Eighth Grade of Elementary School, 2018) clearly put forward such educational outcomes which presuppose different cognitive processes (e.g. comprehending, retelling, interpreting, describing, creating, expressing, etc.), the highest being the independent use of the foreign language for personal and creative purposes (e.g., taking part in communication while adhering to the sociocultural norms of the language, expressing one's own needs and interests) and dealing with novel situations, expressing and arguing one's point of view, etc. The planned outcomes for the two grades differ primarily in terms of the aspects of knowledge to be acquired, not so much in relation to students' ability to use the language for executing tasks at different levels of cognitive complexity. In other words, it is intended that students develop and utilize the same cognitive processes in the two grades using level-appropriate language.

In the English language classroom, as a content-dependent domain, it is important, and as previously seen, obligatory, to improve students' ability to operate with and use the knowledge of the foreign language at different levels of cognitive complexity. In alignment with the prevailing approach to language teaching nowadays - the communicative approach, the ultimate goal of foreign language learning is the independent use of the foreign language by a learner in real-life, unrehearsed situations (Brown, 2001, p. 43). In the same vein, the general prescribed objectives for foreign language learning that all European countries need to comply with outline a general progression in foreign language learning from using the language in strictly controlled, familiar contexts (level of understanding or application), to using it in less familiar ones (level of application or analysis), and on to usage in totally new ones (level of synthesis or evaluation) (Council of Europe, 2002, p. 24). This only indicates a tendency to gradually develop the skills of the students regarding what they can do with the gathered linguistic input. Thus, the teaching of cognitive processes in the 
domain of the foreign language classroom can be applied successfully to learning and/or improving language skills, such as reading (Wilson, 2016) and speaking (Rubin, 2017) since both require a gradual progression from controlled activities (at the application or analysis level) to free ones (synthesis or evaluation level). Moreover, even when acquiring language knowledge, such as vocabulary or grammar, a student can improve or build different cognitive capacities. For example, when practicing vocabulary, students may be given a text from which some words have been omitted and they may be asked to complete the text with their own words (application level) or with the words provided (level of understanding). Whenever students are faced with a language problem, i.e., a task to solve, they are prompted to use their domain-specific cognitive processes.

The combination of cognitive processing development and foreign language learning is beneficial for many reasons: it leads to the gradual acquisition of knowledge, which is more easily subsumed into the existing knowledge base; it is retained far longer than material learned through rote learning; it increases the general critical thinking capacity of students as they can transfer the critical thinking pattern to other domains; it can boost students' motivation as they are active participants and their opinions are valued; it provides better chances for the application of the acquired knowledge; it resembles real-life situations and thus equips students with those abilities and skills they will need in their everyday living.

In order to understand fully what each level represents and what foreign language activities may be done at each stage, the authors provide the following list of foreign language activities, which is a modification of a list proposed by Bobrowski (2006):

Table 1

Modified model of the teaching/learning process of cognitive processes in the foreign language classroom proposed by Bobrowski (2006)

\begin{tabular}{|c|c|c|c|c|}
\hline $\begin{array}{l}\text { Level of Bloom's } \\
\text { Taxonomy }\end{array}$ & Description & Key words & Example questions & Example language activities \\
\hline Knowledge & $\begin{array}{l}\text { Recalls information, definitions, } \\
\text { descriptions, facts; } \\
\text { Can cite or recognize accurate } \\
\text { information regarding a } \\
\text { question; } \\
\text { Has some sense of what } \\
\text { information is relevant. }\end{array}$ & $\begin{array}{l}\text { Who, what, where, } \\
\text { when, which; } \\
\text { Find, choose, define, } \\
\text { list, label, show, spell, } \\
\text { match, name, tell, } \\
\text { recall, select, organize, } \\
\text { outline. }\end{array}$ & $\begin{array}{l}\text { What is ...? } \\
\text { Where is ...? } \\
\text { When did ...? } \\
\text { Can you recall ...? } \\
\text { Can you select ...? }\end{array}$ & $\begin{array}{l}\text { Complete the sentences } \\
\text { with the appropriate form of } \\
\text { the verb to be in the Present } \\
\text { Simple tense. }\end{array}$ \\
\hline Understanding & $\begin{array}{l}\text { Understands a concept, } \\
\text { process, context etc.; } \\
\text { Can process answers to critical- } \\
\text { inquiry questions and articu- } \\
\text { late what remains unclear; } \\
\text { Has some understanding of } \\
\text { how a certain item of knowl- } \\
\text { edge is linked with other items } \\
\text { in the knowledge base. }\end{array}$ & $\begin{array}{l}\text { How, why; } \\
\text { Relate, compare, con- } \\
\text { trast, illustrate, trans- } \\
\text { late, infer, demonstrate, } \\
\text { summarize, interpret, } \\
\text { show, explain, classify, } \\
\text { select, rephrase, distin- } \\
\text { guish, order, compare } \\
\text { and contrast. }\end{array}$ & $\begin{array}{l}\text { How did ... happen? } \\
\text { How would you } \\
\text { describe ...? } \\
\text { What is meant by ...? } \\
\text { Can you explain what } \\
\text { is happening ...? }\end{array}$ & $\begin{array}{l}\text { Complete the sentences with } \\
\text { one of the following words } \\
\text { provided. }\end{array}$ \\
\hline
\end{tabular}




\begin{tabular}{|c|c|c|c|c|}
\hline Application & $\begin{array}{l}\text { Can apply and transfer } \\
\text { particular knowledge to } \\
\text { new situations; } \\
\text { Can teach this knowledge } \\
\text { to others. }\end{array}$ & $\begin{array}{l}\text { Apply, construct, } \\
\text { make use of, plan, } \\
\text { build, develop, model, } \\
\text { interview, experiment } \\
\text { with, identify. }\end{array}$ & $\begin{array}{l}\text { How would you use ...? } \\
\text { What would result if ...? } \\
\text { What elements } \\
\text { would you choose } \\
\text { to change ...? }\end{array}$ & $\begin{array}{l}\text { Complete the sentences with } \\
\text { an appropriate present tense. }\end{array}$ \\
\hline Analysis & $\begin{array}{l}\text { Can solve complex problems } \\
\text { by applying and generalizing } \\
\text { concepts; } \\
\text { Can produce a solution that } \\
\text { is reusable and transferable } \\
\text { to similar solutions. }\end{array}$ & $\begin{array}{l}\text { Analyze, dissect, } \\
\text { inspect, divide, simplify, } \\
\text { solve, test, examine. }\end{array}$ & $\begin{array}{l}\text { What inferences can } \\
\text { you make? } \\
\text { What conclusions } \\
\text { can you draw? } \\
\text { What would } \\
\text { happen if ...? }\end{array}$ & $\begin{array}{l}\text { Indicate which word does } \\
\text { not belong to each of the fol- } \\
\text { lowing groups of words and } \\
\text { explain why. }\end{array}$ \\
\hline Synthesis & $\begin{array}{l}\text { Synthesis of the acquired } \\
\text { knowledge and production of } \\
\text { something unique. }\end{array}$ & $\begin{array}{l}\text { Analyze, dissect, } \\
\text { inspect, divide, simplify, } \\
\text { solve, test, examine. }\end{array}$ & $\begin{array}{l}\text { Can you suggest } \\
\text { solutions ...? } \\
\text { Can you illustrate ...? }\end{array}$ & $\begin{array}{l}\text { Describe one of the two } \\
\text { people in the pictures. }\end{array}$ \\
\hline Evaluation & $\begin{array}{l}\text { Makes new linkages among } \\
\text { concepts and problem solu- } \\
\text { tions which have not been } \\
\text { seen before; } \\
\text { Makes judgments about the } \\
\text { value of something. }\end{array}$ & $\begin{array}{l}\text { Theorize, design, } \\
\text { formulate, discover, } \\
\text { make up, hypothesize, } \\
\text { prove, invent, create an } \\
\text { original work. }\end{array}$ & $\begin{array}{l}\text { How feasible is the } \\
\text { plan to ...? } \\
\text { Can you predict } \\
\text { the outcome if ...? } \\
\text { What is necessary } \\
\text { to discover ...? }\end{array}$ & $\begin{array}{l}\text { Write an essay containing } \\
250 \text { to } 500 \text { words, describing } \\
\text { and evaluating the foregoing } \\
\text { poem. In your description you } \\
\text { should employ such terms as } \\
\text { will reveal your recognition } \\
\text { of formal characteristics of } \\
\text { the poem. Your principles of } \\
\text { evaluation should be made } \\
\text { clear / although they should } \\
\text { not be deliberately described } \\
\text { or defended. (Taken from } \\
\text { Bloom et al., 1956: 198) }\end{array}$ \\
\hline
\end{tabular}

Even though both Bloom et al. (1956) and Anderson et al. (2001) claim that the taxonomy can be applied both for setting teaching/learning and assessment goals, it is questionable how English language teachers around the world make use of it (Beaumont, 2010, p. 1). However, drawing on the ideas of Dimitrijević (1999, p. 54, 122, 225-226) and Hughes $(2003$, p. 1) that we can test only what we taught and in the manner in which it was taught, it suffices to say that if we promote cognitive processing in our classroom, then we should correspondingly test it by giving students tasks that would require them to exhibit cognitive capabilities at different levels of complexity while solving language tasks. Unfortunately, literature regarding testing cognitive processes in the domain of the English language barely exists. One of the two directly relevant papers the authors came across is that by Fahim, Bagherkazemi, and Alemi (2010), who found that those students who performed well on a Watson-Glaser Critical Thinking Appraisal measuring general CT skills performed better on EFL tests as well, which might imply that solving English language tasks involves using one's thinking capabilities. The second paper, written by Yanning (2017), reports on positive correlations between the students' critical thinking and writing scores in the second language classroom. 


\section{Methodology}

\section{Context}

The participants in this study were 14 English language teachers from both urban and rural primary schools in Serbia, aged 30-45 and with 2-23 years of teaching experience. The research was conducted in 2017 and it included contacting teachers of English and asking them to share with the third author some of their self-made tests for assessing their students' knowledge of the language. All teachers who consented to participation taught both seventh- and eighth-graders and shared one test for each grade. Moreover, the obtained tests were achievement tests measuring the quality of accumulated knowledge after a certain period of learning. By quality of knowledge, we mean the use of language information acquired for solving language tasks that require different kinds of manipulation of that information, i.e., different cognitive processes. The authors made use of teacher-made tests for this purpose since it is supposed they contain only that content which was previously covered in class (Dimitrijević, 1999, p. 68).

The seventh and eighth grades were chosen with a clear purpose in mind, as these students had been learning English for at least 7 or 8 years and had probably achieved sufficient language proficiency to enable them to use the language for communicative purposes in a variety of situations.

\section{Procedure}

The received tests were analyzed in the following manner: having carefully studied the definitions, descriptions, and examples of the six levels of cognitive processing given by Bloom et al. (1956, p. 62-197), as well as the recommendations put forward by Bloom et al. (1956, p. 45-59) regarding the classification of tasks, the authors then went about the meticulous task of assigning to every test task a corresponding level of Bloom's Taxonomy while carefully considering the instruction for the tasks and assuming, as previously stated, that the entire content of the test had been previously covered. Once a level was determined for each task, the authors compared their ratings. In cases where discrepancies emerged, the researchers analyzed those tasks again and compared them against the relevant descriptions and definitions. Once a consensus was reached with respect to each individual task, the authors counted the number of tasks at each of the levels of Bloom's Taxonomy in order to ascertain the number of tasks at each level included in the analyzed tests for a certain grade.

\section{Results}

Fourteen tests were analyzed for the seventh grade, comprising 60 tasks altogether. As presented in Table 2, the prevailing levels at which these tasks operated were understanding ( 28 tasks), followed by knowledge ( 14 tasks), and application (14 tasks). Only a few tasks could be classified as demanding higher-order cognitive processes ( 3 - analysis and 1 - synthesis). 
Table 2

Levels of cognitive processing in tests for seventh-graders

\begin{tabular}{|c|c|c|}
\hline $\begin{array}{l}\text { Level of } \\
\text { Bloom's } \\
\text { Taxonomy }\end{array}$ & $\begin{array}{l}\text { Number of } \\
\text { tasks at this } \\
\text { level }\end{array}$ & Examples of types of tasks \\
\hline Knowledge & 14 & $\begin{array}{l}\text { Translate the following words into English; } \\
\text { Match the words on the left with their synonyms on the right; } \\
\text { Complete the sentences with an appropriate form of be going to; } \\
\text { Order the given words to form a sentence. }\end{array}$ \\
\hline Understanding & 28 & $\begin{array}{l}\text { Read the text and answer the questions in full sentences; } \\
\text { Complete the sentences with one of the following words; } \\
\text { Complete the dialogue using someone, somewhere, something etc. }\end{array}$ \\
\hline Application & 14 & $\begin{array}{l}\text { Complete the sentences using the passive voice in an appropriate tense; } \\
\text { Complete the following sentences with an appropriate past tense; } \\
\text { Write sentences using the given words. }\end{array}$ \\
\hline Analysis & 3 & $\begin{array}{l}\text { Name } 3 \text { things that make you happy, three that stress you and three } \\
\text { things parents should do to keep their children healthy. } \\
\text { Indicate the word that does not belong to each group and explain why } \\
\text { it does not belong. } \\
\text { Indicate which of the following sentences are in the Present Simple. }\end{array}$ \\
\hline Synthesis & 1 & $\begin{array}{l}\text { Describe one of the two people in the pictures - what he/she looks like } \\
\text { and is like. } \\
\text { Complete the sentences with your own ideas. }\end{array}$ \\
\hline
\end{tabular}

Evaluation

0

Total:

60

A closer look at individual teachers' tests (Table 3 ) reveals that there are teachers who completely excluded from their tests tasks at the first level (see tests 3, 8, 9, 11, and 14). Rather, their tests contained only understanding and application tasks (see tests 3 and 11) or understanding and synthesis (see test 13). One test contained tasks at rather challenging levels of the Taxonomy (test 8), whereas test 14 contained only one task with the aim of assessing students' ability to apply knowledge, rather than simply recall it.

Table 3

Levels of cognitive processing in individual teacher's tests for the seventh grade

\begin{tabular}{|c|c|c|c|c|c|c|}
\hline & Knowledge & Understanding & Application & Analysis & Synthesis & Evaluation \\
\hline Test 1 & 3 & 2 & & & & \\
\hline Test 2 & 1 & 2 & 1 & & & \\
\hline Test 3 & & 4 & 1 & & & \\
\hline Test 4 & 1 & 5 & & & & \\
\hline
\end{tabular}




\begin{tabular}{|c|c|c|c|c|c|c|}
\hline Test 5 & 2 & & 2 & & & \\
\hline Test 6 & 2 & 2 & & 1 & & \\
\hline Test 7 & 2 & 2 & 1 & & & \\
\hline Test 8 & & & 3 & 1 & & \\
\hline Test 9 & & 2 & 1 & 1 & & \\
\hline Test 10 & 1 & 3 & 1 & & & \\
\hline Test 11 & & 3 & 2 & & & \\
\hline Test 12 & 1 & 1 & 1 & & & \\
\hline Test 13 & 1 & 2 & & & 1 & \\
\hline Test 14 & & & 1 & & & \\
\hline Total: & 14 & 28 & 14 & 3 & 1 & 0 \\
\hline
\end{tabular}

The analyzed tests for eight-graders included 14 tests comprising 66 tasks altogether. The results given in Table 4 show that these tests were composed almost exclusively of tasks at the two lowest levels of the Taxonomy ( 25 tasks at the knowledge level and 29 at the level of understanding). Only four tasks belonged to the higher-order levels ( 3 - analysis and 1 - synthesis).

Table 4

Levels of cognitive processing in tests for eighth-graders

\begin{tabular}{|c|c|c|}
\hline $\begin{array}{l}\text { Level of } \\
\text { Bloom's } \\
\text { Taxonomy }\end{array}$ & $\begin{array}{l}\text { Number of } \\
\text { tasks at this } \\
\text { level }\end{array}$ & Examples of types of tasks \\
\hline Knowledge & 25 & $\begin{array}{l}\text { Circle the correct form of the verb to be in each passive sentence. } \\
\text { Complete the sentences with was/were +ing. } \\
\text { Give examples of the following geographical items that are preceded by the. }\end{array}$ \\
\hline Understanding & 29 & $\begin{array}{l}\text { Order the sentences to form a dialogue. } \\
\text { Paraphrase the sentences using the words in brackets. } \\
\text { Match the words and their definitions. }\end{array}$ \\
\hline Application & 8 & $\begin{array}{l}\text { Complete the sentences with the Past Continuous or Past Simple tense. } \\
\text { Complete the sentences with } a \text { or the where necessary. If the article is not needed, } \\
\text { put } x \text {. } \\
\text { Make a question for each of the following sentences so that the bolded word is the } \\
\text { answer. }\end{array}$ \\
\hline Analysis & 3 & $\begin{array}{l}\text { Are the following characteristics good or bad? } \\
\text { Circle the word that does not belong to the group according to a certain criterion. } \\
\text { Read the text and the descriptions of people and decide which person is the best } \\
\text { candidate for each position. }\end{array}$ \\
\hline Synthesis & 1 & Complete the sentences with your own ideas. \\
\hline Evaluation & 0 & - \\
\hline Total: & 66 & \\
\hline
\end{tabular}


The analysis of individual teachers' tests for eighth-graders (Table 5) shows that all but three teachers (tests 4, 13 and 14) employed elements at the knowledge level. Teachers mainly combined tasks which function at the first two levels. Only seven of them incorporated tasks functioning at the application level (see tests 1, 2, 4, 10, 11, 12 and 13) and when such elements were used, only one such task was present per test, with the exception of test 2 (containing two tasks at the level of application). This is in contrast to the practice these same teachers displayed in the tests for seventh-graders, in which it was not uncommon to find two or three application-level tasks in a single test (see Table 3 , tests 5,8 and 11$)$.

Table 5

Levels of cognitive processing in individual teachers' tests for the eighth grade

\begin{tabular}{|c|c|c|c|c|c|c|}
\hline & Knowledge & Understanding & Application & Analysis & Synthesis & Evaluation \\
\hline Test 1 & 1 & 3 & 1 & 1 & & \\
\hline Test 2 & 3 & & 2 & 1 & & \\
\hline Test 3 & 3 & 1 & & & & \\
\hline Test 4 & & 3 & 1 & & & \\
\hline Test 5 & 2 & 2 & & & & \\
\hline Test 6 & 2 & 2 & & & & \\
\hline Test 7 & 2 & 4 & & & & \\
\hline Test 8 & 4 & & & 1 & & \\
\hline Test 9 & 3 & 2 & & & & \\
\hline Test 10 & 1 & 2 & 1 & & & \\
\hline Test 11 & 3 & 2 & 1 & & & \\
\hline Test 12 & 1 & 3 & 1 & & & \\
\hline Test 13 & & 3 & 1 & & 1 & \\
\hline Test 14 & & 2 & & & & \\
\hline Total: & 25 & 29 & 8 & 3 & 1 & 0 \\
\hline
\end{tabular}

\section{Discussion}

The findings are surprising in that the same teachers were found to have given more lower-order cognitive tasks to older students. In other words, far more tasks at the lowest level of Bloom's Taxonomy were given in the eighth grade than in the seventh grade. Moreover, a smaller number of application-level tasks were given to eighth-graders than to seventh-graders, whereas the numbers of understanding, analysis, and synthesis tasks were nearly identical. This is indicative of a general trend among the teachers to give 
eighth-graders tasks that simply require their recall of information. Such findings lead to the conclusion that the tasks given to eighth-graders for the purpose of assessing their knowledge of English are cognitively easier than those given to seventh-graders. The authors acknowledge that the knowledge of rules, definitions, and paradigms in a language is the basis for performing more complex thinking protocols, and they do agree with the claim of Bloom et al. (1956, p. 32-36) that there are a number of justifications for the teaching of knowledge, but they believe that such levels of cognitive processing should not be predominant either in language teaching or testing (as is the case with the analyzed tests) since it decreases students' communicative competence and deprives them of the opportunity to use language creatively. This is especially true in cases involving students who have been learning a language for a number of years and therefore would be expected to function as relatively autonomous language users.

Generally speaking, the findings are in accordance with what Bloom et al. (1956, p. 89) claimed to be a trend both in schools and at colleges - the emphasis on those intellectual abilities and skills that involve comprehension. However, since testing should be a reflection of the teaching process (Dimitrijević, 1999, p. 54, 122, 225-226; Heaton, 1990, p. 13; Hughes, 2003, p. 1) and the tasks the test is composed of should be those types of tasks that were practiced during the learning process (Dimitrijević, 1999, p. 122), the findings are discouraging, as the participant teachers displayed an inclination to ask eighth-graders to simply regurgitate information (knowledge level) despite their cognitive and linguistic abilities being well beyond this level. Since the ultimate goal of language learning is communication, the transferability of the knowledge displayed by the students of the participant teachers on the actual tests analyzed is doubtful. Tasks at higher levels require language production, not mere recognition and/or remembering, but were quite scarce in the obtained sample. Again, if the test situation is reflective of the teaching process, then it appears obvious that eighth-graders had been primarily taught rules and definitions and had not been given many opportunities to apply or use knowledge for communication. On the other hand, seventh-graders seem to have been taught to more fully understand and apply knowledge rather than to simply recall isolated pieces. Moreover, an analysis of the individual tests (Tables 3 and 5) shows that some of the tests for seventh-graders at times contained not a single task on the first level of thinking, whereas several tests for eighth-graders were composed predominantly of tasks at the lowest levels (Table 5, tests 3, 8, 9).

The findings indicate that the prevailing testing approach among the participants is the structuralist approach (Heaton, 1990, p. 15), which is indicative of a somewhat traditional teaching style. However, an important element must be taken into consideration here - courses in foreign language assessment at English language departments in Serbia have only recently been introduced; hence, the participant teachers may not have received any formal education regarding test construction. That said, we must not jump to the conclusion that their teaching is reflected in their tests, as should be the case, since they may not be aware of this priority. Moreover, the participant teachers were probably not acquainted with the notion of critical thinking or cognitive processes during their formal education and likely have encountered only few occasions when they could have 
received some information about it during their professional development, ${ }^{2}$ so they must not be criticized for not including tasks at different levels of cognitive complexity in their tests. In this light, they should certainly be held more accountable for assessing their students' knowledge of rules and definitions than for assessing these students' free and creative use of the language, despite their students having studied English for at least 7 years (since the first grade of elementary school). A justification for such a decision may lie in the fact that the types of tasks the teachers appear to use in their tests are objective and easy to score, whereas the tasks requiring knowledge production (typically those operating at the higher levels of Bloom's Taxonomy) may imply subjectivity on the part of the teacher in grading, something which they may be seeking to avoid.

\section{Conclusions and implications}

On the one hand, the results of this research are encouraging. Namely, in contrast to the observation made by Glušac and Pilipović (2017) that a growing number of English language teachers tend to use the tests that come along with the course book they are using, the teachers contacted by the authors who chose to cooperate and share their tests for the sake of the study designed the tests themselves in attempting to assess their students' knowledge. On the other hand, an analysis of the levels of cognitive processing required in these tests revealed that the complexity of tasks did not increase with age, but rather decreased. If such a finding reflects the manner of teaching, then the results are rather unsettling. If the findings reflect the participant teachers' lack of knowledge of critical thinking in general or cognitive processes and how they can be tested, then they should be provided with opportunities to gain insight into these elements immediately, as success in both their further education and the job market their students will soon encounter has largely depended on one's thinking abilities for quite some time now.

On the other hand, it may be unreasonable to make judgments regarding the levels of cognitive processing involved based on isolated tests these teachers decided to share with us, which had been developed for particular grades, since these teachers may be using a battery of tests containing a range of tasks that assess different levels of thinking. However, when examining the collected sample of tests, it appears obvious that there is an inclination among participant teachers towards utilizing a more or less similar approach to testing - that which focuses mainly on language elements and lower-order cognitive processes. Such testing is probably the result of the structuralist approach to teaching, a finding which the authors did not intend to discover, but which is a valuable revelation nonetheless. Among others, Heaton (1990, p. 10) warns against such focus-onform practice as it can "indeed have a harmful effect on the communicative teaching of the language." Moreover, as the participants are likely lacking a formal education in test design, they may be designing tests that do not really reflect their teaching practice. In other words, they may be employing an approach that is not structuralist, yet relying on

2 Since 2006, there has been only one accredited seminar entitled "Developing critical thinking in EFL" in the academic years of 2014/2015 and 2015/2016. (Link for accredited seminars since 2006: http://zuov.gov.rs/katalozi-programa-stalnog-strucnog-usavrsavanja/) 
that approach in testing. Should this assumption be proven correct, that would mean that they are violating one of the fundamental principles of testing - to assess in a manner that reflects the way the students were taught. Anderson et al. (2001, p. 254) warn against instructional and assessment activities not being aligned, since it decreases the instructional validity of the assessment and the likelihood of students' good performance on external tests.

Furthermore, the research presented may contain a number of additional limitations, such as the different determinations of levels of cognitive complexity by different researchers, possible failure in not placing the analyzed tests in a relevant educational context, or the issue of not having obtained information regarding the origin of the tests analyzed (whether the contacted teachers designed or borrowed them), all of which might significantly impact the reading of the findings.

\section{Acknowledgement:}

The authors are indebted to the reviewers for their insightful comments and suggestions, which significantly increased the precision of our thought and readability of the paper.

\section{References}

Anderson, L. W., Krathwohl, D. R., Airasian, P. W., Cruikshank, K. A., Mayer, R. E., Pintrich, P. R., Raths, J., \& Wittrock, M. C. (2001). A Taxonomy for Learning, Teaching, and Assessing. A Revision of Bloom's Taxonomy of Educational Objectives. (Complete Edition). New York: Longman.

Beaumont, J. (2010). A Sequence of Critical Thinking Tasks. TESOL Journal, 1(4), 427-448. https://doi. org/10.5054/tj.2010.234763

Bloom, B., Englehart, M., Furst, E., Hill, W., \& Krathwohl, D. (1956). Taxonomy of Educational Objectives: The Classification of Educational Goals. New York: Longmans, Green.

Bobrowski, P. (2006). Bloom's Taxonomy - Expanding Its Meaning. Faculty Guidebook, 161-164. Lisle, IL: Pacific Crest.

Brown, H. D. (2001). Teaching by Principles: An Interactive Approach to Language Pedagogy. (Second Edition). White Plains, NY: Longman.

Cohen, M., Salas, E., \& Riedel, S. L. (2002). Critical Thinking:Challenges, Possibilities, and Purpose. Arlington, VA: Cognitive Technologies, Inc.

Council of Europe (2002). Common European Framework of Reference for Languages: Learning, Teaching, Assessment. Cambridge: Cambridge University Press.

Dimitrijević, N. (1999). Testiranje u nastavi stranih jezika. [Testing in Foreign Language Teaching] Beograd: Zavod za udžbenike i nastavna sredstva.

Facione, P. A. (1990). Critical Thinking: A Statement of Expert Consensus for Purposes of Educational Assessment and Instruction. Millbrae, CA:The California Academic Press.

Fahim, M, Bagherkazemi, M., \& Alemi, M. (2010). The Relationship between Test Takers' Critical Thinking Ability and Their Performance on the Reading Section of TOEFL. Journal of Language Teaching and Research, 1(6), 830-837. https://doi.org/10.4304/jltr.1.6.830-837 
Glaser, R. (1984). Education and Thinking:The Role of Knowledge. American Psychologist, 34(2), 93-104.

Glušac, T., \& Pilipović, V. (2017). Značaj nastavničkih testova u nastavi stranih jezika. [The Importance of Teacher-made Tests in Foreign Language Teaching] Nasleđe, 14(36), 285-297.

Halpern, D. F. (2003). Thought and Knowledge: An Introduction to Critical Thinking (4th Edition). Mahwah, NJ: Lawrence Erlbaum Associates, Inc. Publishers.

Heaton, J. B. (1990). Writing English Language Tests. Harlow: Longman Group UK Limited.

Hughes, A. (2003). Testing for Language Teachers. (2nd edition). Cambridge: Cambridge University Press.

Lai, E. R. (2011). Critical Thinking: A Literature Review. Research Report. London: Pearson.

McPeck, J. E. (1981). Critical Thinking and Education. New York: St. Martins Press.

Mirkov, S., \& Stokanić, D. (2015). Podsticanje kritičkog mišljenja kod učenika: stavovi i aktivnosti nastavnika. [Promoting Students' Critical Thinking: Teachers' Attitudes and Activities] Inovacije u nastavi, 28(1), 25-41.

https://doi.org/10.5937/inovacije1501025M

Paul, R., \& Elder, L. (2008). Critical Thinking: The Nuts and Bolts of Education. Optometric Education, 33(3), 88-91. Retrieved from

https://journal.opted.org/files/Volume_33_Number_3_Summer_2008.pdf

Pešić, J. (2011). Sličnosti i razlike u konceptualizovanju kritičkog mišljenja. [Similarities and Differences in Conceptualizing Critical Thinking] Psihološka istraživanja, 14(1), 5-23.

Pravilnik o nastavnom programu za sedmi razred osnovnog obrazovanja i vaspitanja. [Rulebook on the Curriculum for the Seventh-grade of Elementary School] (2018). Službeni glasnik RS - Prosvetni glasnik, 6/2009, 3/2011, 8/2013, 11/2016, 12/2018. Retrieved from http://www.pravno-informacionisistem.rs/SIGlasnikPortal/eli/rep/pg/ministarstva/pravilnik/2009/6/1/reg

Pravilnik o nastavnom programu za osmi razred osnovnog obrazovanja i vaspitanja. [Rulebook on the Curriculum for the Eighth-grade of Elementary School] (2018). Službeni glasnik RS - Prosvetni glasnik, 2/2010, 3/2011, 8/2013, 5/2014, 11/2016, 7/2017, 12/2018. Retrieved from http://www. pravno-informacioni-sistem.rs/SIGlasnikPortal/eli/rep/pg/ministarstva/pravilnik/2010/2/4/reg

Rubin, R. (2017). Developing Your Students' Vocabulary and Grammar for Critical Thinking. American English Webinar Series 6. Regional English Language Office of the US Embassy, Hanoi. Retrieved from https://vn.usembassy.gov/wp-content/uploads/sites/40/2017/04/AE-Webinar-Series6-Vietnam.pdf

Wilson, K. (2016). Critical Reading, Critical Thinking: Delicate Scaffolding in English for Academic Purposes (EAP). Cognitive Processes and Creativity, 22, 256-265.

https://doi.org/10.1016/j.tsc.2016.10.002

Yanning, D. (2017). Teaching and Assessing Critical Thinking in Second Language Writing: An Infusion Approach. Chinese Journal of Applied Linguistics, 40(4), 431-451. https://doi.org/10.1515/cjal2017-0025

Примљено: 02.07.2018.

Коригована верзија рада примљена: 08. 03.2019.

Прихваћено за штампу: 19. 03. 2019. 


\title{
Анализа задатака из тестова знања енглеског језика за седми и осми разред у Србији према Блумовој таксономији
}

\author{
Татјана Глушац \\ Факултет за правне и пословне студије „Др Лазар Вркатић“, \\ Нови Сад, Србија \\ Весна Пилиповић \\ Факултет за правне и пословне студије „Др Лазар Вркатић“, \\ Нови Сад, Србија \\ Наташа Марчићев \\ Средња школа, Нови Бечеј, Србија
}

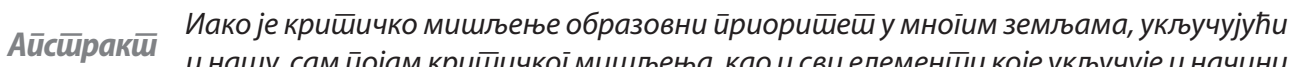
и нашу, сам йојам кришиччкої мишљења, као и сви елемениии које укључује и начини

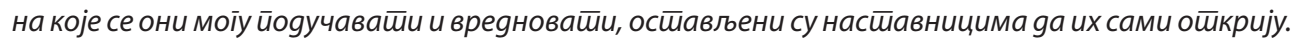

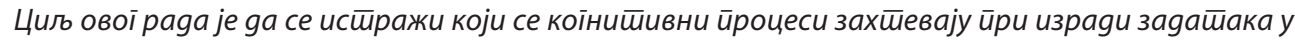
шесейовима знања енїлескої језика за сеgми и осми разреg основне школе у Србији. Узорак се

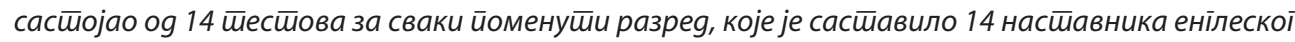

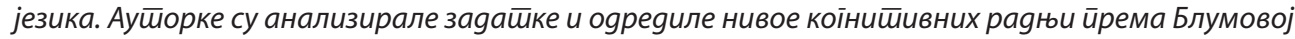

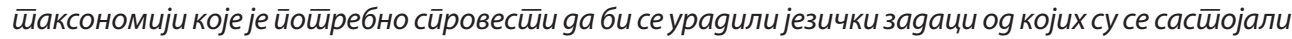
анализирани иеестиови знања. Ауш̄орке су се ирриликом оgређивања нивоа воgиле ойисима

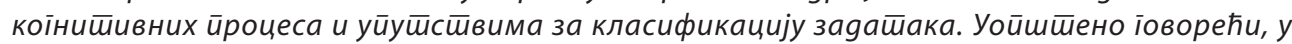

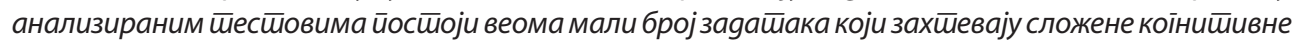

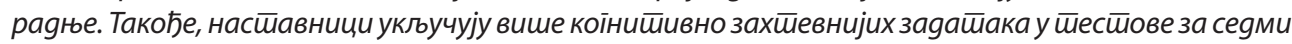

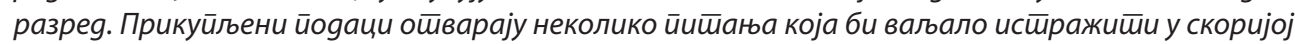

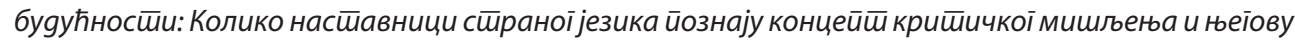

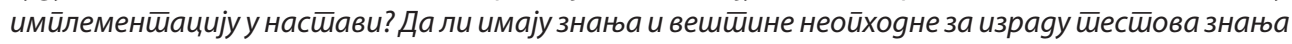

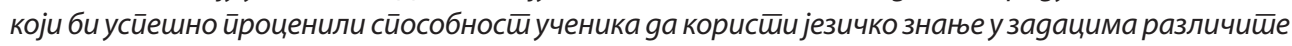
коїнийивне сложеносӣи?
\end{abstract}

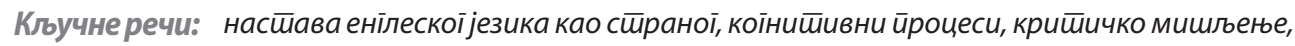

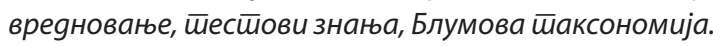




\title{
Анализ заданий тестов по английскому языку для седьмого и восьмого классов в Сербии по таксономии Блюма
}

\author{
Татьяна Глушац \\ Факультет права и бизнеса «Д-р Лазар Вркатич», \\ Нови Сад, Сербия \\ Весна Пилипович \\ Факультет права и бизнеса «Д-р Лазар Вркатич», \\ Нови Сад, Сербия \\ Наташа Марчичев \\ Средняя школа, Нови Бечей, Сербия
}

\begin{abstract}
Резюме Хотя критическое мышление является образовательным приоритетом во многих странах, в том числе и в нашей, понятие критического мышления, а также все его элементы, включая и способы преподавания и оченки, оставлены учителям, чтобы самим их обнаружить. Цель данной работы заключантся в изучении когнитивных прочессов, необходимых при решении заданий тестов по английскому языку для седьмого и восьмого классов основной школы в Сербии. Анализ проведен на примере 14 тестов для каждого из этих классов, которые составлены 14 учителями английского языка. Авторы проанализировали задания и определили уровни когнитивных действий на основе таксономии Блюма, необходимых для выполнения лингвистических заданий анализируемых тестов знаний. При определении уровней авторы руководствовались описаниями познавательных процессов и инструкциями по классификации заданий. В итоге можно сказать что в анализируемых тестах очень мало заданий, требующих сложных когнитивных действий. Кроме того, учителя включают больше заданий с когнотивными требованиями в тесты для седьмого класса. Собранные данные указывают на несколько проблем, которые должны быть изучены в ближайшем будущем, а именно: насколько учителя иностранных языков ознакомлены с концепчией критического мышления и ее применением в преподавании; обладают ли они знаниями и навыками, необходимыми для составления тестов знаний, которые позволили бы успешно оценить способность учащихся использовать лингвистические знания в заданиях различной когнитивной сложности.
\end{abstract}

Ключевые слова: преподавание английского как иностранного языка, когнитивные прочессы, критическое мышление, оченка, проверка знаний, таксономия Блюма. 